\title{
Brief Review on the Controversies around Oil Palm (Elaeis Guineensis Jacq.) Production and Palm Oil Consumption
}

\author{
Godswill Ntsomboh-Ntsefong \\ Department of Plant Biology, Faculty of Science, University of Yaounde I \\ PO Box 812 Yaounde, Cameroon
}

Institute of Agricultural Research for Development, Specialized Centre for Oil Palm Research BP 243 Douala, Cameroon. E-mail: ntsomboh@yahoo.fr

Hermine Ngalle-Bille

Department of Plant Biology, Faculty of Science, University of Yaounde I

PO Box 812 Yaounde, Cameroon

Walter Ajambang

Institute of Agricultural Research for Development, Specialized Centre for Oil Palm Research BP 243 Douala, Cameroon

Benoit Constant Likeng-Li-Ngue

Department of Plant Biology, Faculty of Science, University of Yaounde I

PO Box 812 Yaounde, Cameroon

Institute of Agricultural Research for Development, Specialized Centre for Oil Palm Research BP 243 Douala, Cameroon

Tabi-Mbi Kingsley

Department of Plant Biology, Faculty of Science, University of Yaounde I

PO Box 812 Yaounde, Cameroon

Institute of Agricultural Research for Development, Specialized Centre for Oil Palm Research BP 243 Douala, Cameroon

Joseph Martin Bell (Corresponding author)

Department of Plant Biology, Faculty of Science, University of Yaounde I

PO Box 812 Yaounde, Cameroon. E-mail: josmarbell@yahoo.fr

Emmanuel Youmbi

Department of Plant Biology, Faculty of Science, University of Yaounde I

PO Box 812 Yaounde, Cameroon

Tissue Culture Laboratory, African Centre for Research on Banana and Plantain (CARBAP)

Njombe, Cameroon

Received: May 4, 2016

Accepted: August 9, 2016 Published: August 29, 2016

doi:10.5296/ijrd.v3i2.9418

URL: http://dx.doi.org/10.5296/ijrd.v3i2.9418 


\section{Abstract}

Palm oil from Elaeis guineensis Jacq. of the Arecaceae family is the main traditional cooking oil in most parts of tropical Africa. Oil palm cultivation requires large areas of land and the consumption of crude palm oil from it raises health concerns notably with regards to the incidence of cardiovascular disease and obesity. The industry has therefore been faced with two major controversies. Firstly, palm oil which contains about $50 \%$ saturated fatty acids is considered to be unhealthy for human consumption because its saturated fatty acids raise blood LDL cholesterol level and increase the risk of the above mentioned diseases. Secondly, due to its land intensive nature, the oil palm industry is linked to deforestation, climate change and socioeconomic instability. For these reasons, the oil palm industry has been at the forefront of environmental and reputational challenges. This paper briefly presents an overview of these controversies surrounding the oil palm industry, while highlighting the possible outlets for environmentally friendly production processes and improvement strategies for better oil quality.

Keywords: Oil Palm, Cardiovascular Disease, Environmental protection, Fatty Acids, Obesity, Controversy, Deforestation, Breeding Strategy

\section{Introduction}

The African oil palm (Elaeis guineensis Jacq.) of great economic importance is a perennial crop which originated from Africa in the Gulf of Guinea. Elaeis guineensis belongs to the Arecaceae family and is cultivated in humid tropical regions of Africa, Central and South America and Asia. It is a monocotyledon that produces several products of which palm oil is much solicited in various industries, particularly in the food industry (Corley \& Tinker, 2003). Oil palm as a commodity is considered to play an important role in mitigating climate change, providing alternative sources of energy, and contributing to economic development and rural livelihoods (Feintrenie et al., 2010). Global oil palm cultivated land area, oil yield per unit area, and producer price of palm oil has been on a constant increase since the 1960s. Land area under production has more than quadrupled between 1961 and 2007, while yields and price have also increased substantially (FAO, 2011).

The "varietal types" or fruit forms of the oil palm are commonly defined with reference to shell thickness. The three main fruit forms are: Dura type, of $\mathrm{Sh}+\mathrm{Sh}+$ homozygous genotype, the Pisifera, of Sh-Sh- homozygous genotype and the Tenera type which is a Dura $\mathrm{x}$ Pisifera hybrid of $\mathrm{Sh}+\mathrm{Sh}$ - heterozygous genotype. On the basis of shell thickness, Tenera has been progressively preferred for plantations and is massively produced through controlled pollination of Dura female plants with Pisifera pollen (Jacquemard et al., 1997). The Dura is a wild type of the oil palm. It produces fruits characterized by thick shell (endocarp) and a thin mesocarp yielding about 0.5 tons of palm oil per hectare (Cochard et al., 1997). Pisifera which produces rare fruits that rarely contain shell-less seeds is also considered as a wild type. Very few fructiferous Pisifera do exist and since it is generally abortive, it is used in breeding as the male parent thereby supplying pollen for controlled pollination mentioned earlier. Genetic improvement has led to an increase from $0.5 \mathrm{t} / \mathrm{ha} / \mathrm{yr}$ for wild groves to an average of 
$4.5 \mathrm{t} / \mathrm{ha} / \mathrm{yr}$ for the second cycle Tenera hybrid palms (Cochard et al., 2001; Ngalle et al., 2013).

With the Tenera hybrid used in plantations, the oil palm is the most productive vegetable oil crop in the world (Corley \& Tinker, 2003; Singh et al., 2007). Its oil yield/ha is about ten times greater than soy oil (Hartley, 1988; Durand-Gasselin et al., 2010; Skurtis et al., 2010; Mohd et al., 2011; Jacquemard, 2011). Its main product, crude palm oil (CPO), used in the food, cosmetics and biofuel industries, ensures about $1 / 4$ of world's vegetable oil consumption and represents about $36 \%$ of world's plant oil production whose share of the market is likely to keep increasing in the next decades (Corley, 2009).

About $85 \%$ of global CPO produced is used in food applications (May \& Nesaretnam, 2014). Palm oil is the main traditional cooking oil in most parts of Africa (Corley \& Tinker, 2003) where mostly smallholders produce the readily available commodity for local consumption. It is almost the only oil used for domestic purposes in Southeast Asia, equatorial Africa and represents $46 \%$ of oil consumed in India (Kellens et al., 2007). The olein fraction is widely used as domestic oil in Southeast Asia (Zhang et al., 2013).

Indonesia and Malaysia produce about $85 \%$ of the world's CPO, toping as world's highest producers. In Africa, Nigeria is currently the highest producer followed by Ghana, Cote d'Ivoire, Cameroon, The Democratic Republic of Congo and Angola. Cameroon produced about 270,000 tonnes of CPO from an area of approximately 190,000 ha (Hoyle \& Levang, 2012; Index Mundi, 2016), and stands at the 13th position in terms of world production of CPO (Nkongho et al., 2014). The oil palm thus plays a major role in the economy of these countries by providing employment and wealth. In Cameroon, palm oil assures about $90 \%$ of human dietary oil needs (Hirsch, 1999) with smallholders contributing close to $30 \%$ of palm oil production.

World's demand for comestible oils is poised to increase (Corley, 2009) and there is thus a constant need for continuous genetic and agronomic improvement and expansion of oil crop production (mainly palm oil). However, oil palm cultivation on the one hand is faced with phytosanitary problems (Ngando et al., 2013; Ntsomboh-Ntsefong et al., 2016) and environmental concerns (Chen et al, 2011; Rival \& Levang, 2013). On the other hand, palm oil consumption faces health controversies since it is alleged that oil with high saturated fatty acid content like CPO is detrimental to health (Innis et al., 1994) with regards to cardiovascular disease incidence and obesity (Chong \& Ng, 1991). This paper briefly presents the controversies surrounding the oil palm industry and highlights existing strategies to avert the negative health and environmental effects of the sector.

\section{Controversy on the Health Effects of Palm Oil}

\subsection{Chemical Composition of Palm Oil}

Palm oil is made up of both minor and major components. Triglycerides (TAG) represent the major components alongside small proportions of diglycerides (DAG) and monoglycerides (MAG) (Hilditich \& William, 1964; Sundram et al., 2003). These TAG, DAG and MAG are 
constituted of fatty acids esterified to a glycerol backbone (Mozzon et al., 2013). The minor components are free fatty acids (FFA) and phytonutrients like carotenes, vitamin E (tocopherol and tocotrienoids), phytosterols, phospholipids, phenolic acids, flavonoids, phosphatides, alcohols and sterols (Sambanthamurthi et al., 2000; Sundram et al., 2003). Fatty acids (FA) are classified as saturated fatty acids (SFA), monounsaturated fatty acids (MUFA) and poly-unsaturated fatty acids (PUFA) (Jacquemard, 2011; Sundram et al., 2003). Palm oil is made up of a mixture of polyunsaturated, monounsaturated and saturated fatty acids (Eqbal et al., 2011). The four main FA of palm oil are: palmitic acid (16:0), stearic acid (18:0), oleic acid (18:1), and linoleic acid (18:2) (Rival \& Levang, 2013).

The oil contains approximately an equal amount of saturated and unsaturated fatty acids. Amongst the saturated fatty acids, palmitic and stearic acid account for $45 \%$ and $5 \%$ of the total fatty acids, respectively (Eqbal et al., 2011). Of the 50\% unsaturated fatty acids, most is monounsaturated oleic acid (Corley \& Tinker, 2003; Chowdhury et al., 2007). Palmitic acid varies between 27 and 64\% while oleic acid varies between 23 and $54 \%$ in E. guineensis (Corley \& Tinker, 2003).

\subsection{Brief on the Health Effects of Palm Oil}

Health agencies have been warning about the health hazards of excessive intake of dietary fats, especially of those rich in saturated fats (Chong \& Ng, 1991). World Health Organization (WHO) forecasts that the incidence of cardiovascular diseases and obesity is to rise strongly in the nearest future in Africa! Studies have shown an association between diet and the incidence of coronary heart disease. High fat intake appears to increase the risk of heart disease and saturated fats seem to be more harmful than unsaturated. A high blood cholesterol level is also associated with an increased risk of heart disease (Corley \& Tinker, 2003). Cholesterol is found in the blood in two main forms, in complexes with either high-density lipoprotein (HDL-C) or low-density lipoprotein (LDL-C). It is high levels of the latter form that are associated with heart disease risk, with HDL-C being neutral or perhaps beneficial (Cotrell, 1991; Corley \& Tinker, 2003). Palmitic acid increases low density lipoprotein cholesterol (LDL) in blood.

Palm oil is also considered to cause cancer due to formation of acrylamide at high frying temperatures. The study of acrylamide formation has been performed on several vegetable oils (Morgan, 1942; Foot et al., 2007). Acrylamide is classified as probably carcinogenic to humans by the International Agency for Research on Cancer (IARC) (IARC, 1994). Neurological effects have been observed in humans exposed to acrylamide (Alarcon, 1976; Mottram et al, 2002; Muchtaridi et al., 2012. Glycerol is degraded to acrolein, the unpleasant acrid black and irritating smoke, when oil is heated or fried at temperatures above the smoke point $\left(260-290^{\circ}\right)$, which is higher (Tareke et al, 2002; Zyzak et al, 2003) for oils with higher content of saturated fatty acids and lower content of polyunsaturated acids like palm oil (Lingnert et al, 2002; Muchtaridi et al., 2012). However, there is some evidence that palm oil may inhibit the formation and reduce the growth rate of tumours, but these effects appear to 
be independent of its fatty acid composition, and may be attributed to some of the minor components in the oil.

Another cause for concern with palm oil consumption is its free fatty acid (FFA) content which is raised by lipase activity. Palm fruit mesocarp contains a highly active lipase, which releases FFA from triglycerides (Desassis, 1957; Corley \& Tinker, 2003). The FFA limit for healthy oil consumption is traditionally 5\% (Corley \& Tinker, 2003). The oil palm fruit mesocarp lipase activity necessitates post-harvest inactivation by heat treatment of fruit bunches. E. oleifera has lower lipase activity in mesocarp (Sambanthamurthi et al., 1995; Corley \& Tinker, 2003). This opens up an avenue for introgression of the trait into Elaeis guineensis from Elaeis oleifera. However, such a research endeavor is lengthy and costly. Elite low-lipase lines yielding oil with substantially less free fatty acids than standard genotypes have been identified in Elaeis guineensis. In addition, the oil palm fruit lipase and its gene cosegregates with the low-/high-lipase trait have been identified, providing breeders a marker to rapidly identify potent elite genitors and introgress the trait into major cultivars (Morcillo et al., 2013).

Moreover, it appears that trans-acids in the diet have physiological effects similar to, or more harmful than saturated fatty acids (Corley \& Tinker, 2003). The view that trans-acids should be avoided is gaining strength (Corley \& Tinker, 2003; Enig, 1998) and there is increasing concern over the harmful effects of trans-fatty acids in the diet. Studies have shown that trans-acids tend to increase total cholesterol, and to reduce HDL-C and increase LDL-C levels (Corley \& Tinker, 2003; Sambanthamurthi et al., 2000; Enig, 1998). Fortunately, palm oil is considered a trans fat-free vegetable oil. This may represent a significant market for palm oil since trans-free products can be produced using palm and palm kernel oils as sources of solid fat interesterified with liquid oils. However, companies are recommended to source only palm oil that is deforestation and peat-free (Corley \& Tinker, 2003; Berger, 1996; Goodman, 2015).

\subsection{Basis of the Controversy on Health Effects of Palm Oil}

The principal allegation against palm oil is that it is a highly saturated fat and its consumption supposedly raises the levels of blood cholesterol, thereby increasing the risk of coronary heart disease (Mensah, 2008; De Souza et al., 2015). In the last few decades, controversial studies have reported potential unhealthy effects of palm oil due to its high palmitic acid content (Annamaria et al., 2015). With regards to the allegation of its detrimental health effects (Hiroko \& Desrochers, 2012), palm oil has long been denigrated by its opponents (often producers of potential alternatives) as being "impure, unhealthy, outright dangerous, and a threat to the environment". The past few decades have been marked by a strong publicity conflict over the use of the so called 'tropical oils' in the USA based on a strong campaign launched by the soya bean interests to lessen competition from palm oil and coconut oil (Berger, 1981; Enig, 1998; Corley \& Tinker, 2003). Since coconut oil has decreased in international commerce, palm oil has thus been the main target more so because since 1970, world production and consumption of palm oil, particularly of Malaysian origin have 
increased rapidly. This American Soybean Association campaign against 'tropical oils' actually started in the $1980 \mathrm{~s}$. By then, it was assumed that, because the oil contained $50 \%$ saturated fatty acids, it would behave like other saturated fats (Chong \& Ng, 1991) which had been used in trials. As a result, and in relation to this anti-tropical oils publicity conflict, all saturated fats whether animal or vegetable have been discredited by the saturated fats campaigns. The evidence from metabolic and epidemiologic studies (Hegsted et al., 1965; Keys et al., 1965; Mattson \& Grundy, 1985; Bonanome \& Grundy, 1988) that palmitic acid raises the serum total cholesterol concentration greatly fueled the 'tropical oils' campaign.

However, it has been observed that such allegation is based more on myths rather than on facts as it takes little consideration of basic lipid nutrition or the advent of emerging new data; these anti-palm oil campaigns are considered to have been conducted more for economic gains than for genuine concerns of human health. This is reflected by the estimate of intake of tropical oils in the United States amounting to less than $4 \%$ of the daily fat intake and no more than $2.6 \mathrm{~g}$ of palm oil per capita daily (Chong \& $\mathrm{Ng}, 1991$ ). The campaign has had considerable success, as illustrated by the small imports of palm oil into the USA for many years. As stated earlier, the basis for this campaign was the claim that unsaturated fats and (mainly) oils were healthier than saturated fats, as the latter were considered to contribute to heart ailments by leading to a higher blood content of cholesterol.

Since then, numerous feeding trials with palm oil have been done on animals and with human subjects as reviewed by (Sambanthamurthi et al., 2000). The majority of studies showed that, in broad terms, a diet with a high proportion of palm oil as the fat component is as healthy as any other (Corley \& Tinker, 2003). In fact, it is the dose that makes the poison (Hiroko \& Desrochers, 2012; Rival \& Levang, 2013). The history of the controversy has also been reviewed by other workers (Enig, 1998; Sambanthamurthi et al., 2000; Noh et al., 2002).

\subsection{Potential Outlet}

Even though there is controversy over the health effects of palm oil (Chong \& $\mathrm{Ng}, 1991$; Ntsomboh-Ntsefong et al., 2016), it is worthwhile investing towards reduction of saturated fatty acids concentration and increasing the concentration of monounsaturated fatty acids (oleic acid) to improve the dietary quality of palm oil. In this vein, it is possible to select oil palm genotypes that naturally produce palm oil with low saturated fatty acid content. This is feasible given that the heritability of individual fatty acids of palm oil has been put to evidence (Gascon \& Wuidart, 1975; Swe \& Branch, 1986) with good genetic control over the traits (Swe \& Branch, 1986). Improvement could be effective through evaluation of genetic effects (general and specific combining abilities: GCA and SCA) on the performance of hybrids from interesting parental lines (Preetha \& Raveendran, 2008; Wood et al., 1993). In a feasibility screening of some samples collected from crosses used in IRAD La Dibamba, results indicated that La Mé (Côte d'Ivoire) population presents the lowest concentration of saturated palmitic acid (about 34\%), corroborating with results obtained by others (Gascon \& Wuidart, 1975). Further research in this light could eventually lead to generation of new varieties with significantly improved oil quality. 
Obtaining good quality palm oil with high concentration of oleic acid and low saturated palmitic acid content and thus of low melting point will therefore address this issue and open up new perspectives for palm oil both for dietary and other industrial uses.

\section{Controversy on the Environmental Impacts of Oil Palm Production}

The cultivation of oil palm (Elaeis guineensis Jacq.) is faced with phytosanitary problems (Durand-Gasselin et al., 2011) like pest and diseases as well as environmental controversies. Palm oil is well solicited in the biofuel industry (Choo \& Cheah, 2000; Maria \& Helena, 2007; Corley, 2009). Due to the recent high fossil fuel prices, rising demand for energy, and increasing concerns about the implications of fossil fuels on global climate (FAO, 2008a), many countries around the world have resorted to renewable energy resources to secure stable sources of energy. Among all oil crops, the oil palm has the highest potentials in bio diesel production. European Union (EU) and United States of America (USA) are currently the leading markets for, and producers of biofuels. Malaysia is also a leader in biodiesel production with an output of 540 million liters per annum as of 2009. Indonesia follows with the production of 400 million liters in 2010 (Slette \& Wiyono, 2011).

By 2019, Indonesia and Malaysia are forecast to nearly double their production of biodiesel, respectively (Hoh, 2009). Since 2006, biofuels have increasingly attracted the Indonesian government's interest because of their potential to reduce the country's reliance on fossil fuels which the country had depended on for decades to generate revenues to finance development (Beaton \& Lontoh, 2010). In this context, oil palm plantations are an important driver of economic development in Indonesia because they contribute to state revenues and provide employment in rural areas (Feintrenie et al., 2010). However, the extension of oil palm plantations requires large areas of land, usually forest land with high conservation values.

Consequently, establishment of oil palm plantations lead to degradation of the environment, loss of biodiversity and habitats of some living organisms, land tenure issues and social unrest. In Southeast Asia, Conflicts between communities and oil palm companies have resulted almost entirely from lack of transparency, the absence of free, prior, and informed consent and unequal benefit sharing, exacerbated by the absence of clear land rights (Rist et al., 2010). Due to its land intensive nature, the oil palm industry is therefore linked to deforestation (Maria \& Helena, 2007); climate change and instability; the use of inorganic pesticides, herbicides and fertilizers and their effects on the environment; increasing urbanization and consequent reduction in labour; as well as economic and social issues. For these reasons, the oil palm industry has been at the forefront of environmental and reputational challenges (Cochard et al., 1997; Maria \& Helena, 2007; Feintrenie, 2012) partly due to unplanned extension on forest land. Land allocation regulations are not implemented usually because government planners often perceive forest as "idle" or unoccupied land that must be "optimized" for national development (Obidzinski et al., 2012). In fact, plantation development commonly lags for years or decades, but the removal of forest cover is 
considerably faster. Timber extraction usually proceeds more rapidly during the establishment of oil palm plantations on forest land.

Therefore, oil palm controversy stems mainly from concerns with environmental protection, social issues and the conservation of natural species against development (Rival \& Levang, 2013). In Indonesia for instance, some plantation companies have acquired large concession areas that have taken several years, in some cases decades, to be partially developed into plantations, illustrating the general tendency of plantation investors to acquire large areas of forested land at once for economies of scale, long-term planning, and investment in mitigation (Koh \& Wilcove, 2008). Unplanned oil palm development schemes do not adhere to industry standards nor implement relevant codes for sustainability. As mentioned earlier, this unplanned oil palm development therefore widens the gap between gains, social and environmental cost; and leads to the degradation of the forest systems, loss of plant and animal habitats, extreme land degradation and pollution.

The point of departure to minimize these negative trade-offs must begin with a shift from seeing forests as unproductive idle land to a vision of forests as occupied, supportive of rural livelihoods, and providers of important environmental services. This need not impede the flow of economic benefits from oil palm. It is argued that plantation development should continue, but it should focus on none forest land. In spite of the fact that it is always not possible to avoid deforestation in the development of oil palm plantations, through planned oil palm establishment, greater care could be taken to prioritize the use of extensive areas of none forest land.

The most readily available mitigation mechanisms are the recently introduced ISPO (Indonesia Sustainable Palm Oil) and RSPO standards. The inception of the Roundtable for Sustainable Palm Oil (RSPO) into the oil palm industry stands as an interesting opportunity for sustainable oil palm breeding and production. The RSPO held the first inaugural meeting with the adoption of its Statement of Intent in 2003 (based on initial idea by WWF since 2001) and was officially established under Article 60 of the Swiss Civil Code in 2004 (RSPO, 2016). RSPO consists of palm oil producers, processors, traders, consumers, manufacturers, retailers and non-governmental organizations (NGOs), who develop the principles and criteria for a sustainable palm oil industry, and facilitate the development of sustainable palm oil production (Durand-Gasselin et al., 2011; Rajanaidu et al., 1989). The proposed RSPO guidelines (Principles and criteria) include commitment to transparency, compliance with all applicable local, national and ratified international regulations, adoption of sustainable cultivation practices (Feintrenie, 2012) (including water management, pesticide control and soil erosion), conservation of resources and biodiversity (HCVs-high conservation values) and community development. The way out of the environmental and reputational controversies could certainly be a systematic follow-up and respect of such RSPO guidelines in palm oil production processes coupled with proper exploitation of research results and crop improvement endeavours. 


\section{Conclusion and Perspectives}

Elaeis guineensis has been the subject of intentional selection since the advent of commercial oil palm plantations in Asia (Sumatra and Malaysia) and Africa (Zaire) around 1920. Research work on the oil palm has mostly focused on selection for disease tolerance and quantitative increase of oil yields (Barcelos et al., 2015). Few studies have been done in view of improving the quality of palm oil especially regarding its saturated fatty acids composition (Van Der Vossen, 1974; Gascon \& Wuidart, 1975; Noiret. \& Wuidart, 1976; Billotte et al., 2010; Montoya et al., 2013; Montoya et al., 2014; De Souza et al., 2015). Acknowledging the fact that there has been a serious campaign to denigrate palm oil for decades does not cancel the fact that irrational intake of saturated fats could increase the risk of cardiovascular disease incidence and obesity among consumers. With regards to this controversy over the health effects of palm oil, it can be concluded that it is the dose that makes the poison (Hiroko \& Desrochers, 2012; Rival \& Levang, 2013; Ntsomboh-Ntsefong et al., 2016).

However, this debate has highlighted the importance and urge for researchers to work towards reduction of saturated fatty acids concentration and an increase in the concentration of monounsaturated fatty acids (oleic acid) in order to improve the dietary quality of palm oil. Besides, it is strongly recommended that oil palm breeders continue to work on intensification and yield increase in order to limit expansion of planted areas, thereby reducing the negative impacts of oil palm cultivation on the environment. On their part, commercial oil palm producers should implement good agricultural practices as stated out in the RSPO principles and criteria or guidelines so as to enhance sustainable development of the sector.

Despite the controversies surrounding the oil palm industry, and with reference to the bulk of scientific knowledge developed so far from diverse studies on the oil palm and other plants (Van Der Vossen, 1974; Noiret \& Wuidart, 1976; Corley \& Tinker, 2003; Singh et al., 2007; Kellens et al., 2007; Billotte et al., 2010; Singh et al., 2013; Montoya et al., 2014), it could be interesting if this crop is considered beyond just serving economic interests. The oil palm (Elaeis guineensis Jacq.) could constitute a pertinent biological or murine model for scientific development. Producers, consumers and policy makers should take into consideration health and safety as well as sustainability standards developed by governmental, intergovernmental and private institutions to regulate the environmental and social conditions of production, while securing economic viability (Fuchs \& Kalfagianni, 2010; Fuchs et al., 2011; Kurth \& Glasbergen, 2016).

\section{References}

Alarcon, R. A. (1976). Formation of acrolein from various amino acids and polyamines under degradation at 100 degrees C. Environ Res, 12, 317-326.

Annamaria, M., Imperlini, N. E., Montagnese, C., Aurora, D., Orrù, S., \& Pasqualina, B. (2015). Biological and Nutritional Properties of Palm Oil and Palmitic Acid: Effects on Health. Molecules, 20, 17339-17361. http://dx.doi.org/10.3390/molecules200917339 
Barcelos, E., Rios, S. A., Cunha, R. N., Lopes, R., Motoike, S. Y., Babiychuk, E., Skirycz, A., Kushnir, S. (2015). Oil palm natural diversity and the potential for yield improvement. Front. Plant Sci., 6, 190. http://dx.doi.org/10.3389/fpls.2015.00190

Beaton, C., \& Lontoh, L. (2010). Lessons learned from Indonesia's attempts to reform fossil-fuel subsidies. International Institute for Sustainable Development, Winnipeg, Manitoba, Canada. Retrieved from http://www.iisd.org

Berger, K. G. (1981). Food uses of palm oil. Palm Oil Res. Inst. Malaysia, Occ. Paper, 2, $1-30$.

Berger, K. G. (1996). Food uses of palm oil, Malaysian Palm Oil Promotion Council. Kuala Lumpur.

Billotte, N., Jourjon, M. F., Marseillac, N., Berger, A., Flori, A., Asmady, H., Adon, B., Singh, R., Nouy, B., Potier, F., Cheah, S. C., Rohde, W., Ritter, E., Courtois, B., Charrier, A. \& Mangin, B. (2010). QTL detection by multi-parent linkage mapping in oil palm (Elaeis guineensis Jacq.). Theor. Appl. Genet., 120(8), 1673-187. http://dx.doi.org/10.1007/s00122-010-1284-y

Bonanome, A., \& Grundy, S. M. (1988). Effect of dietary stearic acid on plasma cholesterol and lipoprotein levels. N. Engl. J. Med, 318, 1244-1248. http://dx.doi.org/10.1056/NEJM198805123181905

Chen, B. K., Seligman, B., Farquhar, J. W., \& Goldhaber-Fiebert, J. D. (2011). Multi-Country analysis of palm oil consumption and cardiovascular disease mortality for countries at different stages of economic development. Global Health, 7(45), 1980-1997. http://dx.doi.org/ 10.1186/1744-8603-7-45

Chong, Y. H., \& Ng, T. K. (1991). Effects of palm oil on cardiovascular risk. Med J Malaysia, 46(1), 41-50.

Choo, Y. M., \& Cheah, K. Y. (2000). Biofuel. In: Advances in oil palm research, Vol. 2. In Y., Basiron, B. S. Jalani, \& K. W. Chan (Eds.), Malaysian Palm Oil Board, Kuala Lumpur (pp. 1293-1345).

Chowdhury, K., Banu, L. A., Khan, S., \& Latif, A. (2007). Studies on the fatty acid composition of edible oil. Bangladesh J. Sci. Ind. Res., 42(3), 311-316.

Cochard, B., Adon, B., Kouame, R. K., Durand-Gasselin, T., \& Amblard, P. (2001). Intérêts des semences commerciales améliorées de palmier à huile (Elaeis guineensis Jacq.). Oléagineux, Corps Gras, Lipides, 8(6), 654-658. http://dx.doi.org/10.1051/ocl.2001.0654

Corley, R. H. V. (2009). How much palm oil do we need? Environmental Science \& Policy, 12(2), 134-139. http://dx.doi.org/10.1016/j.envsci.2008.10.011

Corley, R. H. V., \& Tinker, P. B. (2003). The oil palm (4th ed.). Blackwell Science: Oxford Malden MA. Retrieved from http://www.blackwellpublishing.com 
Cottrell, R. C. (1991). Introduction: Nutritional aspects of palm oil. Amer. J. Clin. Nutr., 53(Supp1.), 989S-1009S.

De Souza, R. J., Mente, A., Maroleanu, A., Cozma, A. I., Ha, V., Kishibe, T., Uleryk, E., Budylowski, P., Schunemann, H., Beyene, J., \& Anand, S. S. (2015). Intake of saturated and trans unsaturated fatty acids and risk of all-cause mortality, cardiovascular disease, and type 2 diabetes: Systematic review and meta-analysis of observational studies. BMJ, 351, 3978. http://dx.doi.org/10.1136/bmj.h3978

Desassis, A. (1957). Palm oil acidification. Oléagineux, 12, 525-534.

Durand-Gasselin, T., Blangy, L., Picasso, C., de Franqueville, H., Breton, F., Amblard, P., Cochard, B., Louise, C., \& Nouy, B. (2010). Sélection du palmier à huile pour une huile de palme durable et responsabilité sociale. Oléagineux, Corps Gras, Lipides, 17(6), 385-92. http://dx.doi.org/10.1051/ocl.2010.0343

Durand-Gasselin, T., de Franqueville, H., Breton, F., Amblard, P., Jacquemard, J. C., Syaputra, I., Cochard, B., Louise, C., \& Nouy, B. (2011). Breeding for sustainable palm oil. Paper presented at the International Seminar on Breeding for Sustainability in Oil Palm, held on 18 November, 2011 in Kuala Lumpur, Malaysia. Jointly organized by the International Society for Oil Palm Breeders (ISOPB) and Malaysian Palm Oil Board (MPOB), 2011, pp. 178-193.

Enig, M. G. (1998). Palm oil and the anti-tropical campaign: Good news towards counteracting a decade's worth of damage. In Proc. 1998 Int. Oil Palm Conf. 'Commodity of the past, today and the future' (Ed. by A. Jatmika et al.), 1998, pp. 115-126, Indonesian Oil Palm Res. Inst., Medan, Indonesia.

Eqbal, D., Sani, H. A., Abdullah, A., \& Kasim, Z. M. (2011). Effect of different vegetable oils (red palm olein, palm olein, corn oil and coconut oil) on lipid profile in rat. Food and Nutrition Sciences, 2, 253-258.

FAO. (2008a). Food and Agriculture Organization of the United Nations (FAO). Biofuels: prospects, risks and opportunities. FAO, Rome, Italy.

FAO. (2011). Food and Agriculture Organization of the United Nations (FAO). Rome, Italy.

Feintrenie, L. (2012). Transfer of the Asian model of oil palm development: From Indonesia to Cameroon. World Bank Conference on Land and Poverty. Washington DC, USA, 2012.

Feintrenie, L., Chong, W. K., \& Levang, P. (2010). Why do farmers prefer oil palm? Lessons learnt from Bungo district, Indonesia. Small-Scale Forestry, 9(3), 379-396. http://dx.doi.org/10.1007/s11842-010-9122-2

Foot, R. J. et al. (2007). Acrylamide in fried and roasted potato products: A review on progress in mitigation. Food Addit Contam, 24(Suppl 1), 37-46.

Fuchs, D., \& Kalfagianni, A. (2010). The causes and consequences of private food governance. Business and Politics, 12(3), 1-34. http://dx.doi.org/10.2202/1469-3569.1319 
Fuchs, D., Kalfagianni, A., Clapp, J., \& Busch, L. (2011). Introduction to symposium on private agrifood governance: Values, shortcomings and strategies. Agriculture and Human Values, 28(3), 335-344. http://dx.doi.org/10.1007/s10460-011-9310-5

Gascon, J. P., \& Wuidart, W. (1975). Amélioration de la production et de la qualité de l'huile d'Elaeis guineensis Jacq. Oléagineux, 30(1), 1-4.

Goodman, L. (2015). FDA Bans Trans Fats: What Does This Mean for Palm Oil Consumption in the US? Union of Concerned Scientists: Science for a healthy planet and safer world. Tropical Forest \& Climate Initiative, June 16, 2015. Retrieved from http://blog.ucsusa.org/lael-goodman/fda-bans-trans-fats-what-does-this-mean-for-palm-oil-co nsumption-in-the-us-761

Hartley, C. W. S. (1988). The Oil Palm (Tropical agriculture series) (3rd ed.). Longman Scientific \& Technical, Harlow, London.

Hegsted, D. M., McGandy, R. B., Myers, M. L., Stare, F. J. (1965). Quantitative effects of dietary fat on serum cholesterol in man. Am. J. Clin. Nutr., 17, 281-295.

Hilditich, T. P., \& William, P. N. (1964). The chemical constitution of natural fats (4th ed.). London: Chapman and Hall.

Hiroko, S., \& Desrochers, P. (2012). The health, environmental and economic benefits of palm oil. IEM's Economic Note, 1-4.

Hirsch, R. D. (1999). La filière huile de palme au Cameroun dans une perspective de relance. Agence Française de Développement.

Hoh, R. (2009). Malaysia: Biofuels annual report 2009. USDA Foreign Agricultural Service, Washington, D.C., USA.

Hoyle, D., \& Levang, P. (2012). Oil palm Development in Cameroon. An ad hoc working paper prepared by WWF, IRD and CIFOR.

IARC. (1994). Monographs on the Evaluation of Carcinogen Risk to Humans: Some Industrial Chemicals. Lyon: International Agency for Research on Cancer.

Index Mundi. (2016). Palm Oil Production by Country in 1000 MT, 2016. Retrieved from http://www.indexmundi.com/agriculture/?commodity=palm-oil

Innis, S. M. (1994). Dyer R, Nelson CM, Evidence that palmitic acid is absorbed as sn-2 monoacylglycerol from human milk by breast-fed infants. Lipids, 29, 541-545.

Jacquemard, J. C. (2011). Le palmier à huile. Versailles; Wageningen (Pays-Bas); Gembloux (Belgique): Editions Quæ; CTA; Presses Agronomiques de Gembloux, 2011.

Jacquemard, J. C., Baudouin, L., \& Noiret, J. M. (1997). Le palmier à huile. In A. Charrier et al. (Eds.), L'amélioration des plantes tropicales (pp. 507-532). CIRAD, Montpellier. 
Kellens, M., Gibon, V., Hendrix, M., \& De Greyt, W. (2007). Palm oil fractionation. Eur J Lipid Sci Technol, 109(4), 336-349. http://dx.doi.org/10.1002/ejlt.200600309

Keys, A., Anderson, J. T., \& Grande, F. (1965). Serum cholesterol response to change in the diet. IV. Particular Saturated Fatty Acids in the Diet. Metabolism, 14(7), 776-787. http://dx.doi.org/10.1016/0026-0495(65)90004-1

Koh, L. P., \& Wilcove, D. S. (2008). Is oil palm agriculture really destroying tropical biodiversity? Conservation Letters, 60-64. http://dx.doi.org/10.1111/j.1755-263X.2008.00011.x

Kurth, L., \& Glasbergen, P. (2016). Serving a heterogeneous Muslim identity? Private governance arrangements of halal food in the Netherlands. Agric. Hum. Values, 23(120), 1-16. http://dx.doi.org/10.1007/s10460-016-9698-z

Lingnert, H. et al. (2002). Acrylamide in food: mechanism of formation and influencing factors during heating of foods. App. Nutr. Food Chem., 46, 159-172.

María, A. A., \& Helena, C. (2007). Biofuels trade and sustainable development: The case of Ecuador's palm oil biodiesel. Working document.

Mattson, F. H., \& Grundy, S. M. (1985). Comparison of effects of dietary saturated, monounsaturated, and polyunsaturated fatty acids on plasma lipids and lipoproteins in man. $J$. Lipid Res, 26, 194-202.

May, C. Y. \& Nesaretnam, K. (2014). Research advancements in palm oil nutrition. Recent advancements in palm oil nutrition. Eur. J. Lipid Sci. Technol., 116, 1301-1315. http://dx.doi.org/10.1002/ejlt.201400076

Mensah, G. A. (2008). Ischaemic heart disease in Africa. Heart, 94(7), 836-843. http://dx.doi.org/10.1136/hrt.2007.136523

Mohd, B. W., Choo, Y. M., \& Chan, K. W. (2011). Strategic directions in oil palm research. In: Further advances in oil palm research (2000-2010) volume 1. In Mohd, B. W., Choo, Y. M. and Chan, K. W. (Eds.), Malaysian Palm Oil Board, Kuala Lumpur, Malaysia( pp. 1-27).

Montoya, C., Cochard, B., Flori, A., Cros, D., Lopes, R., Cuellar, T., Espeout, S., Syaputra, I., Villeneuve, P., Pina, M., Ritter, E., Leroy, T. \& Billotte, N. (2014). Genetic architecture of palm oil fatty acid composition in cultivated oil palm (Elaeis guineensis Jacq.) compared to its wild relative E. oleifera (H.B.K) Cortes. PLoS One, 9(5), 95412. http://dx.doi.org/10.1371/journal.pone.0095412

Montoya, C., Lopes, R., Flori, A., Cros, D., Cuellar, T., Summo, M., Espeout, S., Rivallan, R., Risterucci, A. M., Bittencourt, D., Zambrano, J. R., Alarcón, G. W. H., Villeneuve, P., Pina, M., Nouy, B., Amblard, P., Ritter, E., Leroy, T. \& Billotte, N. (2013). Quantitative trait loci (QTLs) analysis of palm oil fatty acid composition in an interspecific pseudo-backcross from Elaeis oleifera (H.B.K.) Cortés and oil palm (Elaeis guineensis Jacq.). Tree Genet. Genomes, 9(5), 1207-1225. http://dx.doi.org/10.1007/s11295-013-0629-5 
Morgan, D. (1942). Smoke, fire, and flash points of cottonseed, peanut, and other vegetable oils. Journal of the American Oil Chemists' Society, 19, 193-198. http://dx.doi.org/10.1007/BF02545481

Mottram, D. S. et al. (2002). Acrylamide is formed in the Maillard reaction. Nature, 419, 448-449. http://dx.doi.org/10.1038/419448a

Mozzon, M., Pacetti, D., Lucci, P., Balzano, M., \& Frega, N. G. (2013). Crude palm oil from interspecific hybrid Elaeis oleifera $\mathrm{x}$ Elaeis guineensis: fatty acid regiodistribution and molecular species of glycerides. Food Chem., 141(1), 245-252. http://dx.doi.org/10.1016/j.foodchem.2013.03.016

Muchtaridi, M., levita, J., Rahayu, D. \& Rahmi, H. (2012). Influence of Using Coconut, Palm, and Corn Oils as Frying Medium on Concentration of Acrylamide in Fried Tempe. Food and Public Health, 2(2), 16-20. http://dx.doi.org/10.5923/j.fph.20120202.04

Ngalle, H. B., Bell, J. M., Ngando, E. G. F., Nyobe, L., Ngangnou, F. C., \& Ntsomboh, G. N. (2013). Morphogenesis of oil palm fruit (Elaeis guineensis Jacq.) in mesocarp and endocarp development. Journal of Life Sciences, 7(2), 153-158.

Ngando-Ebongue, G. F., Etta Enow, C., Ntsomboh, G. N., \& Oben Tabi, T. (2013). Breeding oil palm (Elaeis guineensis Jacq.) for fusarium wilt tolerance: An overview of research programmes and seed production potentialities in Cameroon. International Journal of Agricultural Science, 3(5), 513-520.

Nkongho, R. N., Feintrenie, L., \& Levang, P. (2014). Strengths and weaknesses of the smallholder oil palm sector in Cameroon. Oilseeds \& fats Crops and Lipids-OCL, 21(2), D208. http://dx.doi.org/10.1051/ocl/2013043

Noh, A., Rajanaidu, N., Kushairi, A., Mohd Rafil, Y. \& Mohd Din, A. 2002. Variability in fatty acid composition, iodine value and carotene content in the MPOB oil palm germplasm collection from Angola. J. Oil Palm Res., 14, 18-23.

Noiret, J. M., \& Wuidart, W. (1976). Possibilities for improving the fatty acid composition of palm oil. Results and prospects. Oleaginous, 31(11), 465-474. Retrieved from http://www.cabdirect.org/abstracts/19771651732.html

Ntsomboh-Ntsefong, G., Ngando-Ebongue, G. F., Ajambang, W., Maho-Yalen, J. E., Tabi-Mbi, K., Arondel, V., Bell, J. M. \& Youmbi, E. (2016). Chapter 10-Oil Palm-In Breeding Oilseed Crops for Sustainable Production, Gupta. San Diego: Academic Press. http://dx.doi.org/10.1016/B978-0-12-801309-0.00010-0

Obidzinski, K., Andriani, R., Komarudin, H. \& Andrianto, A. (2012). Environmental and social impacts of oil palm plantations and their implications for biofuel production in Indonesia. Ecology and Society, 17(1), 25. http://dx.doi.org/10.5751/ES-04775-170125 
Preetha, S. \& Raveendran, T. S. (2008). Combining ability and heterosis for yield and fibre quality in Line $\times$ Tester Crosses of upland cotton (Gossypium hirsutum L.). Int. J. Plant Breed. Genet., 2, 64-74. doi: 10.3923/ijpbg.2008.64.74

Rajanaidu, N., Rao, V., Abdul Halim, H. \& Ong, A. S. H. (1989). Genetic resources: New developments in oil palm breeding. Elaeis, 1(1), 1-10. http://agris.upm.edu.my:8080/dspace/handle/0/3755

Rist, L., Feintrenie, L. \& Levang, P. (2010). The livelihood impacts of oil palm: smallholders in Indonesia. Biodiversity and Conservation, 19(4), 1009-1024. http://dx.doi.org/10.1007/s10531-010-9815-z

Rival, A. \& Levang, P. (2013). Palms of controversies: Oil palm and development challenges. Bogor, Indonesia: CIFOR. Translated from Rival A \& Levang P, 2013. La palme des controverses: Palmier à huile et enjeux de développement. Versailles, France: Éditions Quæ.

RSPO (2016). Round Table on Sustainable Palm Oil. Retrieved from April 6, 2016, http://www.rspo.org/about

Sambanthamurthi, R., Oo K. C. \& Parman, S. H. (1995). Factors affecting lipase activity in Elaeis guineensis mesocarp. Plant Physiol. Biochem., 33, 353-359. http://dx.doi.org/10.1007/978-94-015-8394-7_155

Sambanthamurthi, R., Sundram, K., \& Tan, Y. (2000). Chemistry and biochemistry of palm oil. Prog Lipid Res, 39 (6), 507-558. PMID:11106812. doi:10.1016/S0163-7827(00)00015-1

Singh, R., Jayanthi, N., Soon-Guan, T., Jothi, M. P., \& Cheah, S. C. (2007). Development of simple sequence repeat (SSR) markers for oil palm and their application in genetic mapping and fingerprinting of tissue culture clones. Asia Pacific Journal of Molecular Biology and Biotechnology, 15 (3), 121-132.

Singh, R., Ong-Abdullah, M., Low, E. T., Manaf, M. A., Rosli, R., Nookiah, R., Ooi, L. C., Ooi, S. E., Chan, K. L., Halim, M. A., Azizi, N., Nagappan, J., Bacher, B., Lakey, N., Smith, S. W., He, D., Hogan, M., Budiman, M. A., Lee, E. K., DeSalle, R., Kudrna, D., Goicoechea, J. L., Wing, R. A., Wilson, R. K., Fulton, R. S., Ordway, J. M., Martienssen, R. A., \& Sambanthamurthi, R. (2013). Oil palm genome sequence reveals divergence of interfertile species in Old and New worlds. Nature, 500 (7462), 335-339. doi:10.1038/nature12309

Skurtis, T., Aïnaché, G., \& Simon, D. (2010). Le financement du secteur de l'huile de palme : pourquoi les institutions financières de développement doivent continuer à investir en Afrique. Oléagineux, Corps Gras, Lipides, 17 (6): 400-403. doi:10.1051/ocl.2010.0346

Slette, J. P., \& Wiyono, I. E. (2011). Oilseeds and products update 2011. USDA Foreign Agricultural Service, Washington, D.C., USA, 2011.

Sundram, K., Sambanthamurthi, R., \& Yew-Ai, T. (2003). Palm fruit chemistry and nutrition. Asia Pacific J. Clin. Nutr., 12(3), 355-362. 


\section{Macrothink}

International Journal of Regional Development

ISSN 2373-9851

2016, Vol. 3, No. 2

Swe, S. T. \& Branch, W. D. (1986). Estimates of Combining Ability and Heterosis among Peanut Cultivars. u(2), 70-74. http://dx.doi.org/10.3146/i0095-3679-13-2-7

Tareke, E. et al. (2002). Analysis of acrylamide, a carcinogen formed in heated foodstuffs. $J$ Agric Food Chem, 50, 4998-5006. http://dx.doi.org/10.1021/jf020302f

Van Der Vossen, H. A. M. (1974). Towards more efficient selection for oil yield in the oil palm (Elaeis guineensis Jacquin). Doctoral thesis, Wageningen.

Wood, R., Kubena, K., Brien, B., Tseng, S. \& Martin, G. (1993). Effect of butter, mono and polyunsaturated fatty acid-enriched butter, trans-fatty acid margarine, and zero trans-fatty acid margarine on serum lipids and lipoproteins in healthy men. J. Lipid Res., 34, 1-11.

Zhang, X., Li, L., Xie, H., Liang, Z., Su, J., Liu, G. \& Li, B. (2013). Comparative analysis of thermal behavior, isothermal crystallization kinetics and polymorphism of palm oil fractions. Molecules, 18(1), 1036-1052. http://dx.doi.org/10.3390/molecules 18011036

Zyzak, D. V. et al. (2003). Acrylamide formation mechanism in heated foods. J Agric Food Chem, 51, 4782-4787. http://dx.doi.org/10.1021/jf034180i

\section{Copyright Disclaimer}

Copyright for this article is retained by the author(s), with first publication rights granted to the journal.

This is an open-access article distributed under the terms and conditions of the Creative Commons Attribution license (http://creativecommons.org/licenses/by/3.0/). 